\title{
INTEGRATION MODEL OF CREATIVE TELEMATICS INDUSTRIES WITH MANUFACTURING INDUSTRY IN WEST JAWA PROVINCE
}

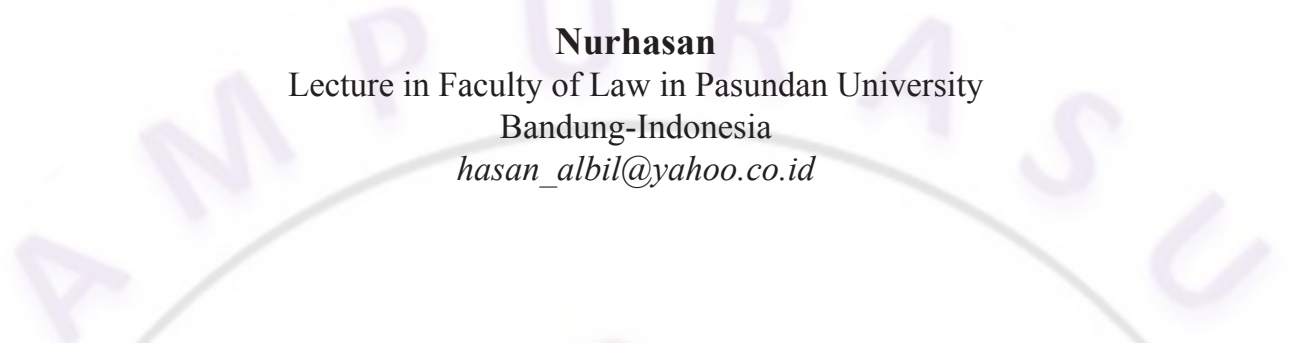

\begin{abstract}
This research is important to integrate activity of Small and Medium Industries of Creative Telematics with the activity of the Manufacturing Industry especially in West Java province, considering the facts or existing condition that between Small and Medium Industries of Creative Telematics and the Manufacturing Industry still run on their own way and there has not been symbiotic mutualism relations and/or orientation of activities between the two levels of industry has not been integrated. There were 14 sub-sectors which are creativity-based industries, namely: 1) Advertising; 2) Architecture; 3) Art Goods Markets; 4) Craft; 5) Design; 6) Fashion; 7) Video, Film, and Photography; 8) Interactive Games; 9) Music; 10) Art performance; 11) Publishing and Printing; 12) Computer and Software Services; 13) Television and Radio; and 14) Research and Development. The creativity-based industries relating with cultural heritage. This study was conducted by using empirical juridical approach. Analysis of the object of research was conducted through legal analysis. The results of this analysis is the drafting of Integration Model of Small and Medium Industries of Creative Telematics in the strengthening of manufacturing industry to increase productivity and competitiveness of industry in west java province.
\end{abstract}

Keywords: model, integration, industry, creative, telematics, manufacture, productivity.

\section{Introduction}

In the preamble of the Law No. 3 of 2014 on Industry, it is stated that the vision and the mission of the national industrial development of Indonesia are: 1) the national development in the field of economy is implemented in order to create a strong economic structure through advanced industrial development as an economic powerhouse that is backed by the strength and the ability of the formidable resources; and 2) the advanced industrial development is realized through the strengthening of the independent, healthy, and competitive industrial structure by utilizing the resources optimally and efficiently, and encouraging industrial development to all parts of Indonesia by balancing the progress and the national economic unity that is based on democracy, justice, and the noble values of national culture by giving priority to national interests.

Regarding the definition of industry, it has been stated firmly in Article 1 of paragraph 2 of Law No. 3 of 2014, that is: "Industry is all forms of economic activity that process raw materials and/or take advantage of industry resources to produce goods having added value or higher benefits, including industrial services."

In general, Creative industries are the small and medium scale enterprises that are specifically regulated in Law No. 20 of 2008 on Micro, Small, and Medium Enterprises,. So, what is meant by Small and Medium Industries of Creative Telematics in this research is the Industry of Creative Telematics having the 
scale of enterprise as a Small enterprise and / or Medium enterprise in general.

The definition of Creative Industries that is currently used by the parties involved in the creative industries is the definition based on UK DCMS Task Force in 1998, that is: "Creatives Industries as those industries which have their origin individual creativity, skill \& talent, and which have a potential for wealth and job reation through the generation and explanation of intellectual property and content."

In the mapping study of the creative industries having been conducted by the Ministry of Trade in 2007. the reference of definition of the creative industries used in Indonesia is: "The industry deriving from the use of creativity, skills and individual talents to create welfare and jobs through the creation and utilization of the creative ability and creation of the individual.“

West Java Province which consists of 26 district/cities with population of about $41,483,729$ inhabitants (the results of regional economic socio survey in 2007) has a lot of Manufacturing Industries and Small and Medium Industries of Creative Telematics. The condition of the special character society with the diverse creativity having economic and prospective value is proved to have a reliable durability of the impact of the global economic crisis pressure and geographically, it plays a big and important role as a buffer zone of the capital of the Republic of Indonesia, Jakarta.

Based on BPS data, the rate of economic growth in West Java in 2005 is of 5.4 percent. Processing Industry sector grew by 7.13 percent, it is still below the building sector/ construction which grew by 17.85 percent. The economic structure of West Java in 2005, if we see from the business sector (BPS data, based on 2000 constant prices), was dominated by three superior sectors. The first contribution is non-oil industrial sector by 41.74 percent, the second contribution is trade sector, namely hotels and restaurants, by 19.23 percent and the third contribution is the agricultural sector by 14,11 percent. In 2005 , the industry growth rate by 7.13 percent. Contributions to the biggest contribution are from the Transport
Equipment Industry, that is Machinery and Equipment by 18.37 percent, from Textile industry, that is Leather Goods and Footwear by 10.17 percent, from Chemical Fertilizer Industry and Rubber Goods by 4.40 percent and from Industrial Food, beverages and tobacco by 4.99 percent.

Regional economic development in West Java as contained in the Plan stretegis is done through the development of six core business, namely development of (1) Human Resources, (2) Agribusiness, (3) Business Marine, (4) Tourism (5) Manufacturing industry, and (6) Manufacture industry and the other services industry. The effort used to boost economic growth and purchasing power are by increasing productivity and investment in the superior sectors ( 6 core business). Based on the results of discussions with stakeholders, the superior products of West Java are the creative industries in general and industry of the creative telematics in particular.

Narrowly, Creative industry is a separate industry, with its creativity, producing creative designs as its main products or its main services. More broadly, Creative Industry is a collection of industry sectors which rely on creativity as the main capital in providing products/services. In that context, Design industry can be viewed as a core component of a Creative Industry and its implementation can occur in several other industrial sectors, such as multimedia, advertising, garment, food, footwear, and the others. West Java has human resources which are rich culture and adequate education. The sources of creativity in the Creative Industries are creative and innovative and they can be used as driving force of development of other industrial sectors. As a center of education, West Java can attract young generation from different regions so that it can increase diversity and variety of local potentials. In addition, it is also also supported by high local potential as a supporter of the Creative Industries such as Sundanese culture, agroindustry, textile industry, handicraft, and the others.

The problems are that the creative industries are new industries and they have not been recognized as the driving wheel of development. In addition, the Inadequate 
infrastructure becomes the obstacle to the development of creative industries. Another problem is the lack of copyright protection to the creative industries inflicting a culture which is not creative (cultural bandwagon, negative thinking).

The goals of the development of creative industries are to connect the business environment for the sake of the creative industries having superior products in the domestic market and to be able to compete in regional markets in the hope of being able to increase the exports value and contribute the manpower absorption, and improve regional income. Strategiy undertaken is by building the capacity of products and services throughout the business value chain of creative industries having the force of copyright through the empowerment of human resources.

Regarding the current condition of creative telematics industries in West Java today, it has been towards the pioneering phase, such as the initiation of the telematics development by Cimahi Government, namely Cimahi Cyber City focusing on the development of software and Cimahi Technoresidential park focusing on the hardware. In the development, the government of Bogor Regency and Shen Zen province, China are coorperating in building technopark by 30 ha. cooperated with, Shen Zen province of China. In addition, the party of university, ITB has launched the use of IGOS on campus. ITB and the Ministtry of Research and Technology are cooperating in developing rural internet and the program of Universal Service Obligation, that is rural telephone program, and forming or establishing BHTV foundation as the telematics community forum in West Java.

The problems in the development of creative telematics industries are there is no representative and adequate place of business for creative telematics industries, such as facilities of the infrastructure of creative telematics industries and facilities of support facilities, there is no forum to accommodate new ideas between educational institutions which create human resources of the creative telematics industries, and research centers of the creative telematics industries, the occurrence of brain drain because of being hijacked of reliable Indonesia human resources of creative telematics industries by overseas company, the high cost of development of creative telematics industries, especially the research of creative telematics industries, the prototype stage and the implementation. For the influx of investors, there should be legal protection and security protection ensuring the adherence and the business continuity in the field of creative telematics industries which will be full of capital, technology, and the capabilities of high human resources.

The Strategies undertaen in developing creative industry of telematics are to grow the small and medium industries of creative telematics and to encourage the technical cooperation and long-term business between support Small Medium industries and market (especially banking).

Payng attention to the development framework and the roadmap for of Creative Telematics in West Java province, it is obvious that facts or existing condition that there is no integration between Small and Medium Idustries of Creative Telematics and the Manufacturing Industry, there is still no mutually beneficial relationship (symbiotic mutualism), and/or there is no integration in the case of the activities orientation of between the two levels of the industries, so that it is reasonable and understandable if the activities of the Small and Medium Industries of Creative in general and Small and Medium Industries of Creative telematics or are bankrupt. because it is directly or indirectly it can be said to be competing with the Manufacturing Industry. These facts indicate that the Government need holistic study results on Integration Model Construction of Small and Medium Industries of Creative Telematics in the strengthening of manufacturing industry to increase productivity and industrial competitiveness in West Java Province.

In particular, this research aims at: (1) investigating, analyzing, and compiling integration model construction of Small and Medium Industries of Creative Telematics in the strengthening of manufacturing industry to increase productivity and industrial competitiveness in West Java, as the law aspired (ius constituendum); and (2) 
socializing, adapting, and applying the results of integration model construction of Small And Medium Industries of Creative Telematics in the strengthening of manufacturing industry to increase productivity and industrial competitiveness in West Java Province.

\section{Method}

This study was conducted by using empirical juridical approach which is oriented towards holistic study and in the process, legal disciplines receive related disciplines. Analysis of the object of research was conducted through legal analysis.

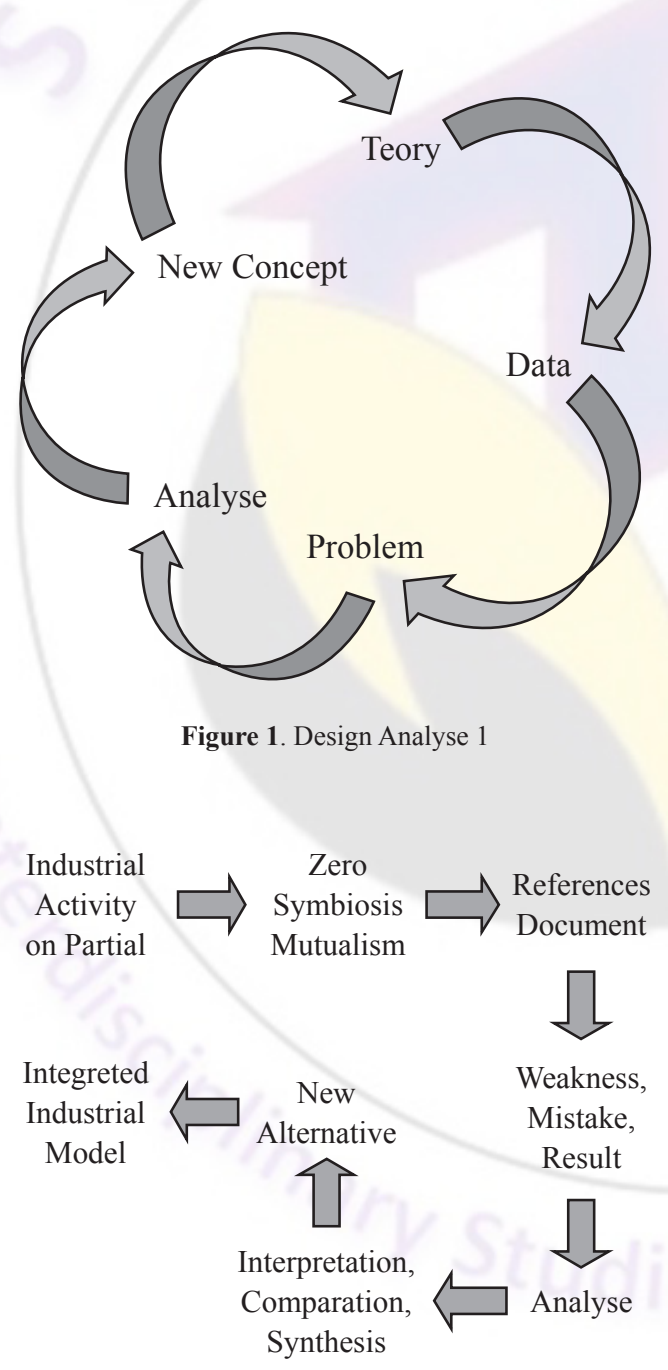

Figure 2. Design Analyse 2

\section{Result and Discussion}

In Indonesia, as it has been stated in the document of Indonesian Creative Economic Development in 2025 published by the Department of Trade in 2008, there were 14 sub-sectors which are creativity-based industries, namely: 1) Advertising; 2) Architecture; 3) Art Goods Markets; 4) Craft; 5) Design; 6) Fashion; 7) Video, Film, and Photography; 8) Interactive Games; 9) Music; 10) Art performance; 11) Publishing and Printing; 12) Computer and Software Services; 13) Television and Radio; and 14) Research and Development.

A good understanding of the value creation chain in the Creative Industries will help the Related stakeholders to understand the position of Creative Industries in a series of industry events. The value chains becoing the main subject in determining the development strategy are as follows: 1) Creation, it consists of education, innovation, expression, confidence, experience and projects, protection, talent agent; 2) Production, it consistis of technology, network outsourcing services, financing schemes; 3) Distribution, it consists of negotiating distribution rights, internationalization, infrastructure; and 4) Commercialization, it consists of marketing, sales, service (services), the promotion of Creative Industries.

Observing the value chain, it indicates that the government policy on the development of the Small and Medium Industries of Creative Telematics should be cross-sectoral and there should be coordination between institutions, so that it is expected to integrate the activities of Small and Medium Industries of Creative Telematics into the activities of the Manufacturing Industry to achieve mutually beneficial relationship.

Cross-sectoral characters are also reflected in the concept of creative economy development known as Analysis of Triple Helix (The building consisting of foundations, the five main pillars, and roof), first proposed by Henry Etzkowitz and Loet Leydesdorff and then they are further developed by Gibson (1994) in The New Production of Knowledge 
and Nowotny (2001 in Re-Thinking Science as follows: 1) Foundation: namely Human Resources (People) as the main asset of the creative industries that characterize almost all of the creative industries subsector; 2) Five Main Pillars: namely industry, technology, resources, institution, and financial intermediary; and 3) Roof: namely building of the creative economy that is protected by the interaction of Triple Helix consisting of intellectuals or scholars, business, and government.

Based on the mapping study of the creative industries implemented by the Department of Trade in 2007, the data obtained is the contribution of creative industries to the economy of Indonesia can be seen in the five main indicators, namely: Gross Domestic Product (GDP), employment, number of companies, export, and impact on other sectors. In 2006, the contribution of creative industries is Rp 104.4 trillion, or an average of $4.75 \%$ to the national GDP during the period 20022006. This amount exceeds the sector's share of electricity, gas, and clean water. Three subsectors contributing the most, namely fashion $(30 \%)$, crafts $(23 \%)$, and advertising $(18 \%)$. Creative industries are also able to absorb 4.5 million workers with a growth rate of $17.6 \%$ in 2006 , far exceeding the growth rate of the national workforce that is only $0.54 \%$, despite the contribution to exports is still only $7 \%$. Although the contribution to exports is still small only $7 \%$. The period $2009-2015$ is mentioned as a basic reinforcement phase. The target is the contribution of the creative industries to the national export is expected to reach $11 \%-12 \%$ and labor absorption is expected to increase in the range of $6 \%$ $7 \%$. The period 2015-2025 is the stage of acceleration in the hope the contribution to GDP is expected to rise to $9 \%-11 \%$, the value of national exports $12 \%-13 \%$, and the employment of $9 \%-11 \%$.

In general, Small and Medium industries of Creative and Small and Medium industries of Creative Telematics in particular are requiring touch of empowerment. The empowerment of Small and Medium industries of Creative must be conducted in an effort to integrate growth factor and equalization factor. The growth of good Small and Medium industries of Creative should be followed and shoud be directly proportional to the achievement of welfare distribution for all perpetrators of Small and Medium industries of Creative. The empowerment of Small and Medium industries of Creative should be interpreted as a planned and integrated effort in order to enable Small and Medium industries of Creative and to make Small and Medium industries of Creative independent. The effort should be started by creating an atmosphere or climate that enables the potential of development of Small and Medium industries of Creative, that is by encouraging, motivating, and raising the awareness of their potential and strive to develop it. Furthermore, the access opening is needed for various opportunities in the hope that Small and Medium industries of Creative are increasingly powerless.

Essentially, the empowerment of Small and Medium Industries of Creative is an integral part of community empowerment. The role of community empowerment is the link between macro development concepts and micro development concepts. Development strategy that rests on partiality and empowerment is understood as a process of transformation in cultural, economics, and social relations, and also in the relation of politics and society. The structural changes expected is a process that takes place naturally, namely anyone who produces the creation should enjoy it and vice versa. Therefore, appropriate intervention in the case of policy at the macro level is very important in supporting the efforts to overcome the gaps that should be done with micro activities for the sake of the benefit of society as the target of the empowerment. The main approach to the concept of empowerment is that society is not the objects of development projects but the society be treated as the subject of the development efforts (Kartasasmita, 1996).

Furthermore, Kartasasmita explained that, development planning oriented community empowerment, should include the following points: 1) to identify the underlying problems that led to gaps; 2) identify the alternatives to solve the problem; 3) sets out some alternatives chosen with regard to the principle of efficiency and effectiveness, taking into account the resources available and can be utilized, as well as the potential to be developed. the alternatives cover: 1) the 
alternative of general macro wisdom, which is valid nationally and should be guaranteed not to harm weak society, and even the macro wisdom should benefit the people both economic position and social status; 2) alternative of sectoral wisdom in relation to the specific sectors and the sectoral wisdom should benefit weak society, and also it should be guaranteed not to harm the weak society, 3) the alternative of the regional wisdom in relation to a region or a specific area ensuring the priority of the public interests 4) the alternative of special wisdom in relation to weak and underdeveloped community groups, and the special wisdom should pay attention to the diversity of society, the diversity of need, the different levels of development, and local conditions. After determining the plan that should be done and how to do it, establishes what will be done and how to do it, the wisdom has to be implemented consistently. paying attention to deal with creative industries which is cross-sectoral character, it means that factor of coordination between strong sectors become important for the success in achieving the purpose. The cause of the weakness in the coordination is the strong sectoral hegemony. (Kartasasmita, 1996).

The foundation of the creative industries is technology. Technology is the result of cultivation or the mirror of the culture in a society. The technology itself is a cultural forming element. Therefore, the culture of a nation greatly affects the progress of technology.Theprogressoftechnologyrequires a creative attitude and the creative attitude is shaped and is influenced by the culture of the society. The society encouraging and appreciating the creativity and the productive work, the culture usually becomes the fertile ground for the development of science and technology. Cultural transformation through technology is a part of the modernization process. However, every effort to develop the technology, although there is scope of macro or of national, has to be adapted to the condition of the communities in which the technology will be developed. Modernization does not mean the implantation of technology, but it can mean the renewal of traditional technology into modern technology supported by scientific principles (Kartasasmita, 1996).
The activities of creative industries usually produce a specific and original intellectual work from the previous intellectual work and of course it needs an adequate legal protection for inventors, creators, formulators, and compilers. With the existing legal protection, it is hoped that it will be able to increase the growth of the creative works and will be able to give significant added value in improving the welfare, the productivity, and the competitiveness in the environment of local, national, regional, and global. The form of legal protection of the intellectual work is to give the Intellectual property rights guaranteed by the law for the sake of its inventor, its creator, its formulators, and its compilers. The Intellectual Property Rights consist of:

\section{a. Copyrights}

Nowadays, legal protection of copyright has been regulated in Law No. 28 of 2014. The basic consideration for the promulgation of the law is that Copyright is the intellectual property in the fields of science, art and literature which has a strategic role in supporting the development of the nation and promote the general welfare, whose development has been so rapid so that require an increase protection and ensuring legal certainty to the creators, holders of copyright and related rights owners. Apart from that, also pay attention to Indonesia has been a member of various international agreements in the field of copyright and related rights so that needed further implementation in the national legal system so that the creators and national creators were able to compete internationally.

The provision of Article 4 to Article 30 of Law No. 28 of 2014 regulates in more detail, including it is affirmed that Copyrights are exclusive rights which consist of moral rights and economic rights.

The provisions of Article 40 of Law No. 28 of 2014 affirm that the copyright works that are protected include copyright works in the fields of science, art and literature.

\section{b. Patern Rights}

Nowadays, legal protection of patent rights has been regulated in Law No. 14 of 2001. The basic consideration for the enactment 
of the Law is that in line with the ratification of international agreements by Indonesia, developments of technology, industry, and increasingly rapid trade, law that can provide reasonable protection for inventors. In the provision of Article 1 paragraph 1 of the Law, it is formulated that patent shall meanis an exclusive right granted by the State to an Inventor for his Invention in the field of technology, for a certain time, to exploit his Invention or to authorize another person to exploit it. In the provision of Article 1 paragraph 2 , it is affirmed that, the invention shall mean an Inventor's idea that is poured in any activity of solving a specific problem in the field of technology, either in the form of a product or a process, or an improvement and development of a product or a process. Patent Rights can be implemented by other parties, through the granting of the License, a license granted by the patent holder to another party based on the agreement of granting rights to exploit the economic benefit of a patent which is protected in the certain period and specific requirements.

\section{c. Industrial Design Rights}

Nowadays, the legal protection of Industrial Design has been regulated in Law No. 31 of 2000. The basic consideration for the enactment of the Law is to advance the competitive industry both in the national trade and in international trade, and to create a climate encouraging community creations and innovations in the field of Industrial Design as a part of the intellectual property rights system. In addition, it is also supported by Indonesian cultural and ethnic richness which is various sources for the development of Industrial Designs.

In the provisions of Article 1 paragraph 1 of Law No. 31 of 2000 , it is formulated that the industrial design is a creation on the shape, configuration or composition of lines or colors, or lines and colors, or a combination in the form of threedimensional or two-dimensional which gives aesthetic impression and it can be realized in a pattern of three-dimensional or two-dimensional and it can be used to produce a product, goods, industrial commodity or handicraft. In Article 1 paragraph 5 of the Law, it is affirmed that the industrial design is an exclusive right granted by the Republic of Indonesia. to a Designer for his creation for a certain time to give his consent to the other parties to implement the rights of industrial design.

Regarding the transfer of rights and the licenses of Industrial Designs, it is regulated in Article 31 untill Article 36 of Law No. 31 of 2000 .

\section{d. Right To Layout-Designs of Integrated Circuits}

Nowadays, legal protection of Integrated Circuit Layout Design has been regulated in Law No. 32 of 2000. The basic consideration for the enactment of the Law is to advance the competitive industry within the scope of both national trade and international trade, and to create a climate that encourages community creation and innovation in the field of Integrated Circuits Layout Designs as a part of the intellectual property rights system.

In the provisions of Article 1 paragraph 1 of Law No. 32 of 2000 , it is formulated that the integrated circuit is a product in the form of finished or semi-finished in which there are various elements and at least one of these elements is an active element which is partly or entirely interconnected and is integrally formed in a semi conductor material intended to produce electronic functions. In Article 1 paragraph 2 of Law No. 32 of 2000 , it is formulated that the Layout Design is the creation in the form of three-dimensional layout designs of various elements, at least one of these elements is an active element, and some or all of the interconnections in an integrated circuit and the three dimensional layouts are intended for the preparation of Integrated Circuits.

Paying attention to the exposure regarding legal protection on a variety of Intellectual Property Rights above, it seems obvious that the legal protection and the appreciation for the intellectual property rights in addition to creating a climate that encourages creation and community innovation, they are always aligned with efforts to improve the industrial competitiveness in order to face increasingly tight competition businesses, especially related to the diverse agreements and international agreements in the field of free trade, both within South East Asia (ASEAN) and global 
For condition in West Java in 2013, the Department of Industry and Trade of West Java Province compile the development framework of Creative Industries and its road map, and specifically the Department of Industry and Trade arranges the development framework of Creative Telematics and its road map. In the implementation, the Department of Industries and Trade of West Java Province coordinates and cooperatse with the related institutions, such as the development of the Creative Industries coordinate and cooperate with the Department of Cooperatives in general and Small and Medium Industries in West Java Province, while related to the development of Creative Industry of Telematics coordinating and cooperating with PT INTI, the institutions in relation to the $\mathrm{d}$ of Telematics Creative Industries in West Java Province has encourage the evelopment have established RICE (Regional IT Center of Excellence) in different regions of the Regency/ City, by taking into account the characteristics of each region, such as RICE Bandung, RICE Cimahi, RICE Bogor, and the others.

Regarding the terminology of Manufacturing Industry, branch of industry applying the industrial machinery, the equipment, the labor, and the process medium of converting raw materials into finished goods for sale (Indag Jabar, 2015: 58). This term can be used for human activities, from crafts to the production with high technology. However, the term is more commonly used in the industrial world, where raw materials are transformed into finished goods on a large scale. Manufacturing exists in all of the fields of economic system. In the free market economy, manufacturing usually means mass production for sale to customers for the sake of obtaing benefit. Some industries such as semiconductor and steel often use the term of fabrication instead of manufacturing. The manufacturing sector is closely related to engineering.

Manufacturing company is a company which processes raw materials into goods that are ready to be marketed. In general, all of the process occurring in the industry involve various modern equipment. A manufacturing company (previously, the manufacture) or plantation factory is a collection of industrial buildings or a complex having several buildings, where workers produce goods or operate machine from one product to another product. Most of modern manufacturing have large warehouses or warehouse, such as facilities containing heavy equipment used for the assembly lines and the production. The type of enterprise usually collects and centralizes all of the resources, the labor, the capital, and the machine in the hope of producing the kind of quality product (Indag Jabar, 2015: 59).

Based on data from the Central Bureau of Statistics (BPS), the growth of manufacturing industry in recent years is still relatively low. In the last 5 years, the non-oil manufacturing industry grew an average of $5.4 \%$, below the national economy which grew an average of $5.9 \%$ peryear and it is far below other industries such as trade, non-oil mining, transport and communication. Lately, the performance of the manufacturing industry increasingly disturbed due to macro-economic challenges being faced today. The latest data shows that there were signs of the weakening of manufacturing industry. Non-oil manufacturing industry only grew by $5: 56 \%$ in 2014 , the previous growth by $6.86 \%$ in the same period in 2013 .

The problem faced by the manufacturing industry today is very structural so that in carrying out industrial policy, the priority becomes very important. For the sake of the medium-term, the industry being able to reduce the pressure on the current account deficit can be given extra attention, namely industries whose export competitiveness is high but the import content is high, such as products of the automotive industry, electronics, food \& beverage, garments, footwear and chemicals through the implementation of the export promotion strategy and the effective import substitution. Then, the policy of industrial downstream based on natural resources in order to be guarded because it can reduce the risk when there are fluctuations in commodity prices and exchange rates. For the longerterm interests, the parent industry, such as steel and petrochemicals, produce the plastic raw material must be developed. With the increasing need of infrastructure, property, and manufacturing industry of Indonesian mainstay, such as automotive industry, consumer goods, and food and drinks, of course, the need of raw materials from steel and plastic will keep increasing. Today, the 
domestic production has not been able to offset the high demand so that the need should be still largely met through imports. the only manufacturing industry having high market power and maintaining the margin such as the cement industry the margin can remain stable due to the inelastic demand so that the margin can be maintained by increasing the selling price amid the increase of production costs

For condition in West Java, as one of the provinces becoming the barometer of industry in Indonesia, almost $90 \%$ of the manufacture of automotive industry and electronics is located in West Java. The biggest contributor to GRPD, West Java is the manufacturing sector $(36.72 \%)$, hotels, trade, and agriculture $(14.45 \%)$, so that the total is of $51.17 \%$. West Java contributed nearly a quarter of the total value of Indonesian production results in the non-oil sector. The main export of textiles is $55.45 \%$ of the total export in West Java. The other exports are in the form of steel, footwear, furniture, rattan, electronics, aircraft components, and etc.

The concept of the development of the manufacturing industry in West Java is a regional thematics base. The aims of regional thematic are 1) to encourage the increase of superior potential utilization of superior regional economy having the potential of the leverage in increasing the consumer purchasing power extensively.; 2) to establish the synergy of economic potential development between the districts/ cities and/ or between sectors integratedly,, effectively, and efficiently; 3 ) to grow the development cooperation between regions so that it focuses on the handling of a programs or activities.

The priority activitiy in $2013-2018$ is divided into four regional coordination of development program (WKPP), namely: 1) WKPP I (Bogor Region); 2) WKPP II (Purwakarta regency, Karawang regency, Subang regency, Bekasi regency, Bekasi city); 3) WKPP III (Cirebon region); 4) WKPP IV (Priangan region).

The priority activities in WKPP I (Bogor region) are: a) to develop the centre of beef cattle, dairy cattle, chicken, and local poultry; b) to develop the agribusiness of freshwater fish and ornamental fish for both regional market and global market; c) to develop the centre of rice breeding of fragrant pandan varieties and the other varieties; d) to develop the ecotourism of landscapes and marine, in the corridor of Bogor-Puncak-Cianjur, Bogor, Sukabumi, Pelabuhan Ratu and to manage Cibodas biosphere reserves; e) to develop the new growth centers in Pelabuhan Ratu and Metropolitan Bodebek Karpur.

The priority activities in WKPP II (Purwakarta regency, Karawang regency, Subang regency, Bekasi regency, Bekasi city) are: a) the development of the manufacturing industry; b) development of ceramics industry and pottery; c) the development of rice and food industry, the processing based on local raw materials, agriculture, fish farming of freshwater and brackish water, dairy cattle, beef, mutton / lamb, chicken, and local poultry; d) development of historical tourism and pilgrimage tourism; e) the development of metropolitan Bodebek Karpur.

The priority activities in WKPP III (Cirebon region) are: a) the industrial development of mango Gedong lipstick and industrialization of fisheries; b) the development of commodity trading system of rice and other crops; c) the development of batik and rattan industry, processed food industry of local raw materials; d) the preservation of the palace, historical tours, historical tours, and develop ecotourism; e) the development of Metropolitan. Cirebon Raya and Region of BIJB and the Aerocity of Kertajati.

The priority activities in WKPP IV (Priangan region), are: a) the development of higher education and integrated research areas in Jatinangor; b) development of clusters of poultry, the fishery of aquaculture and freshwater fishing, dairy cows, beef cattle, Garut sheep, goat and its networks and the development center of fodder production; c) development of productof industrial plants (coffee, tea, cocoa, rubber, essential) and horticulture (vegetables, fruits, ornamental plants) export-oriented; d) the development of trade services, creative industries and tourism; e) the development of Metropolitan Bandung Raya, the center of the new growth of Rancabuaya Pangandaran. 
In relation to the issue of the increased productivity and the industrial competitiveness, the common understanding and the interpretation of meaning of the word 'competition' include very broad scope. They are as follows (Frinces, 2011: 16-17) : 1) the efforts or the activities or or the action to show the superiority of each party (individual, group, organization, company, region, country) in various fields (trade, business, production, products, weapons, games, elections, etc.) with the aim of defeating the opponent. The efforts or the activities or the actions can end in victory or defeat; 2) The interaction of the force with the other force, one organization with the other organizations, one country with the other countries in which each party is trying to build strength and superiority and to empower the strengths and the superiority they have to defeat and dominate the others; 3) A process for seizing a goal or the strategic object either in the form of commodities (goods and services), market, consumer, certain opportunities and things which are interested and seized by many parties to be won and maintained in order to be able to be owned and controlled for the sake strategic interest.; 4) the condition in which the sellers of certain products or services try to seize and sustain the demand of buyers or consumers to be interested in the products or services they sell and they are not controlled by the sellers of other products and services.

Furthermore, Porter and Boyden Lamb identify the aspects related to how to win a competition. The aspects are as follows (in Frinces, 2011: 17-19): 1) to determine the problem in the competition; 2) to formulate the purpose of competition or which would dipersaingkan; 3) to determine the strategic goal of the competition; 4) to determine the scope of competition; 5) to determine when the competition is declared as a starting point of the competition, and when the business or the activities of the competition will be conducted or initiated; 6) to make a comprehensive strategic plan on the agenda of the competition; 7) to make a SWOT analysis (Strength, Weakness, Opportunities, Threaths) to know the strength and weaknesses of the opponent, and critically assess the potential and prospects, whether the competition will be won or lost; 8) to prepare the things that need to be prepared. in conducting the competition,which includes software and hardware.

There are several strategic steps to win the competition (Frinces, 2011: 28-31), namely: 1) always staying ahead of the competitors in the promotion, image formation, the provision of information; 2) The essential elements created have to be better or more superior than competitors; 3) there should be cooperation of service in the case of product or the same effort with other companies; 4) having a new edge; 5) having the absolute superiority in which the competitors will not compete with their superiority, such as: HR High quality, leadership, organization, strategic planning, business strategy, technology, mastery of raw materials, control of energy resources, quality, invention, innovation, promotion, funds, financing and payment systems, networking, communications, transportation, political bargaining position; 6) The strategies and policies, such as: low cost strategy, differentiation strategy, focus strategy, grow strategy, defensive strategy, stabilization strategy, adjustment strategy, survival strategy, offensive strategy, expansion strategy, contraction strategy, recovery strategy, cost leadership strategy, high technology strategy, low cost and high technology strategy, high quality strategy, high price strategy, service strategy, mix strategy, combination strategy, spider web strategy, go together and spilled strategy, turn around strategy, generic strategy, market challenger strategy, competitive strategy, collaborative strategy, co-operative strategy, positioning strategy, alternative strategy, strategic alliance strategy, take now and pay later strategy, promotion and imaging strategy, compatibility strategy.

The competition will encourage perpetrators of competition to conduct good things. for either consumers or customers, (Frinces, 2011: 32) among other things: 1) Bring up the new innovations that encouraging the creation of new technology, and the new technolog will push the activities of research and development; 2) Bring up new products and services that will provide plenty of choice for both consumers and customers; 3) There will be a price war, lower price, granting discount, offering payment system friendly to the buyers; 4) The services will be better and buyers will 
feel more satisfied; 5) Packaging will be more attractive because it is a part of a strategy to attract more buyers; 6) The shape and size of the goods will be more varied and are usually followed by significant price difference that makes a lot choices for shoppers.

The tight competition will also encourage the businessmen or the industrialist to create a competitive superiority of products with specific character through the activities as follows (Partomo and Sartika, 2008): 1) the increase of the design and the quality (upgrading) of industrial products; 2) the increase of local content of industrial results; 3 ) The gradual shift to the production of products having higher added value. It is affirmed that the future industry is an industry having high competitiveness based on the ability, the creativity, the skill, and the professional of human resources. Furthermore. It is affirmed that the future industry is an industry having high competitiveness based on the ability, the creativity, the skill, and the professional of the human resources. The industrial development in future requires cross-sectoral support from the following sectors (Partomo and Sartika, 2008): 1) The development of an innovative and conducive business environment; 2) The linkage to a variety of industrial clusters; 3) The increase of the capability of the resources used by the industry in order to build core competence; 4) The determination of industrial deployment priorities; 5) The development of small and medium industries.

Of course, the overall efforts to realize the goal of national development require the support of the legal aspects in order that everything can be conducted in an orderly manner and based on justice. The indicators of an orderly manner and justice can be realized through: 1) the fair law enforcement without discrimination; 2) the realization of institutions and clean and professional law enforcement agencies; 3 ) the realization of gender justice; 4 ) the realization of justice in income distribution, economic resources, mastery of economic assets, and loss of monopolistic practices.

A fundamental issue that needs serious attention from all of the Indonesian components is it turns out that a number law of products of law have not been directly proportional to the achievement of the level of welfare when a variety of laws is enforced. These issues indicate that the implementation of Construction of Law has not prioritized the welfare of the society.

In relation to the group of industries in Article 101 paragraph 2 of Law No. 3 of 2014, there are three groups of industry, namely: 1) small Industries; 2) medium industries; 3) large industries. What is meant by integrated industrial model in this research is a model of the intregated small, medium, large industrial activities based on the principle of mutuall benefit (symbiotic mutualism) to obtain larger added in strengthening the productivity and industrial competitiveness.

Of course, the integration of the industry has to pay attention to the same vision, mission, and characteristics of each industry group. In general, Creative Industries is still in the small industry. On the other hand, the Manufacturing Industry is generally in medium and large industrial groups. The activities of the manufacturing industry involves creative elements in the form of creation or the inventions or formulation of specific product design in general. Thereby, there are a number of similarities between the activities of the creative industries. After paying attention to the other specifi aspects becoming the characteristics of manufacturing industry, the activities of specific creative industries (for instance: industries of Creative Telematics) enables it to be integrated into the activities of manufacturing industry (for example: Automotive Manufacturing industry, four-wheel vehicles). The integration between the activities of the Creative Industries of Telematics and the activities of automotive Manufacturing Industry in the creation of specific product design (in which there is an element of intellectual property rights, such as: Copyrights, Patents, industrial design, Right to Layout Design of Integrated Circuit) is expected to be able to produce added value of mutual benefit for both of the type of industries in the hope of being able to strengthen the productivity and the industrial competitiveness in facing the competition at the national, regional, and global levels. The integrated industrial model can be illustrated schematically in Figure 3. 


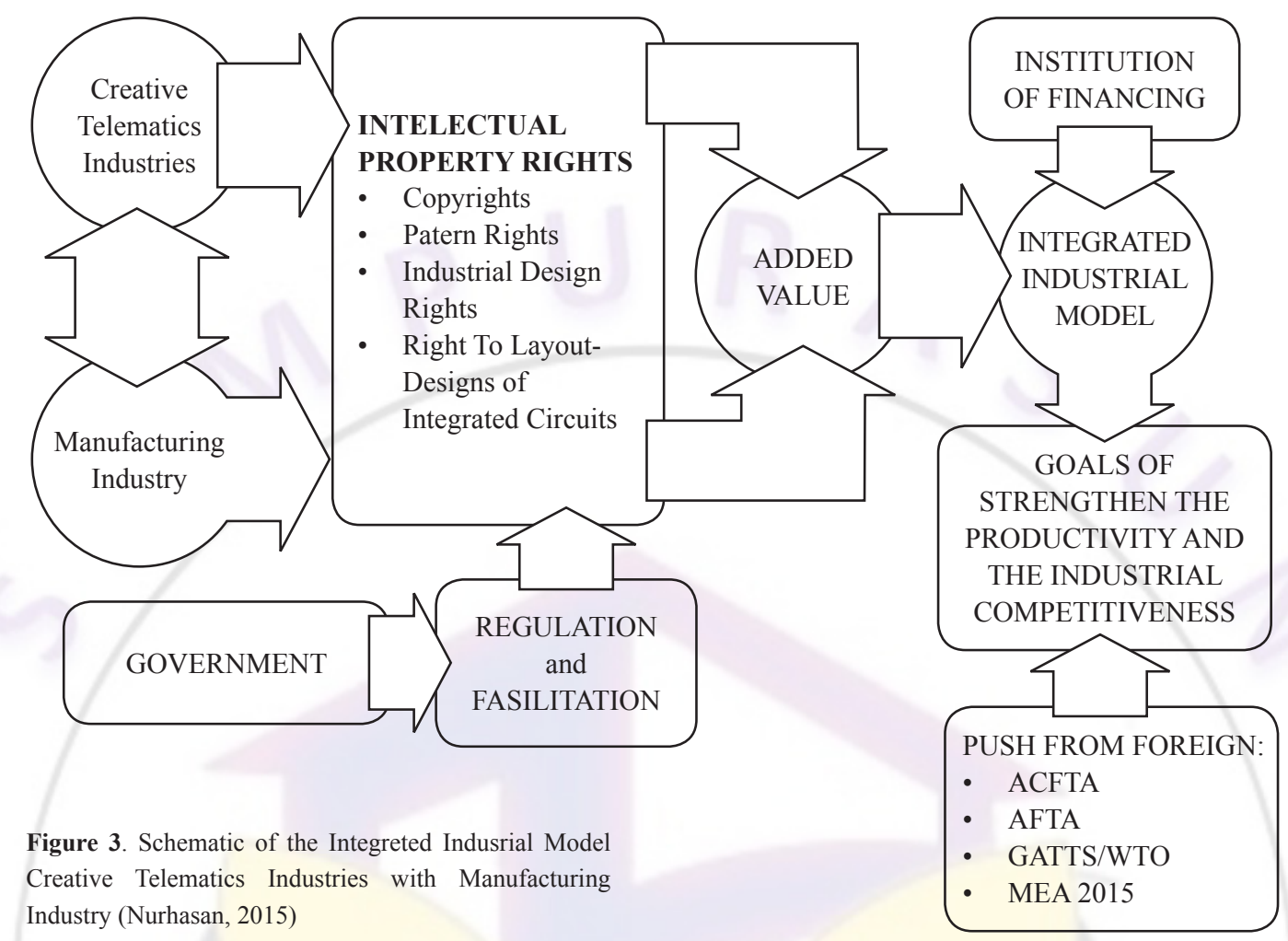

\section{Conclusion}

Based on the explanation of the outcome of the research above, finally the researchers came to the following conclusion:

The results of the activities of the Telematics Creative Industries in West Java Province have not been aimed at the effort to produce Intellectual Property Rights yet (Copyrights, Patents, Industrial Design Rights, Right to Layout Design of Integrated Circuits), whereas the Intellectual Property Rights are the principal and important matters, and have a lot of potential as objects that can be negotiated and integrated with the activities of specific manufacturing industry having the same characteristics and the same need in order to obtain added value which is mutual benefit for both the industries of creative telematics and manufacturing industry;

The research has produced the integration model of Small and Medium Industries of Creative Telematics in the strengthening of specific manufacturing industry to increase productivity and industrial competitiveness in West Java, which can be briefly described as follows: a) Intellectual Property Rights generated by Small and Medium Industries of Creative Telematics either in the form of Copyrights, Patents, Industrial Designs, and The Rights To Layout Design Of Integrated Circuits are appreciated and are utilized, and/ or are empowered by specific manufacturing industry through the mechanism which is agreed together so that both Small and Medium Industries of Creative Telematics and Manufacturing Industry in particular, obtain added value to improve the productivity and industrial competitiveness both locally and nationally, and periodically Small and Medium Industries of Creative Telematics obtain program of technical and assistency management on a specific manufacturing industry in order to meet the standardization of the quality and the quantity of the products in accordance with the standards set by the manufacturing industry in particular, and also to gain greater trust from financial institutions (financial services) to boost its capital base; b) manufacturing industry obtain efficiency and effectiveness in developing the investment in particular both related to the fulfillment of the market demand (design development) 
and related to the production capacity through symbiotic mutualism with Small and Medium Industries of Creative Telematics; c) the government obtained the study holistic as materials to formulate legislation (Act, Government Regulations, Local Laws) in the field of development of Small and Medium Industries OfCreative Telematics in particular, the integrated and sustainable development of industry as well as in an effort to increase the original income in the form of local taxes and levies; and d) financial institutions (financial services) can reduce or minimize the potential for bad loans from the sector of the Small and Medium Industries of Creative Telematics. In the preparation of the model, the choice of the automotive manufacturing industry (four wheel) was considered closer to the characteristic of industries of creative telematics in which it's activities have great potential to produce a design that is required by the automotive manufacturing industry (four wheel), and then it was mass-produced with the utilization period in a relatively long period of time for each design.

Based on the above conclusions, finally the researcher proposes some suggestions as follows:

The activities of industries of Creative Telematics in West Java Province, should be aimed at the efforts to produce Intellectual Property Rights (Copyrights, Patents, Industrial Designs Rights, Right to Layout Design of integrated circuits), because Intellectual Property Rights are the principal and important matters and have a lot of potential as objects that can be negotiated and integrated with the activity of specific manufacturing industry having the same characteristics and the need in order to obtain added value which is mutual benefit for both the industries of creative telematics and the manufacturing industry;

The integration model of Small and Medium Industries of Creative Telematics in the strengthening of manufacturing industry to increase productivity and industrial competitiveness in West Java Province is expected to be implemented through the publication of the government's policy as a regulator and facilitator followed by businesses in the field of Small and Medium
Industries of Creative Telematics and of specific manufacturing industry having the same characterisitcs and the same need.

\section{Acknowledgments}

This papers on behalf of my wife (Nurul), two my girls (Almas and Bilqis), management and colleague in faculty of law, Pasundan University of Bandung, and Government of Indonesia.

\section{References}

Departemen Perdagangan RI. 2008. Pengembangan Ekonomi Kreatif Indonesia 2025.

Frinces, Zein Heflin. 2011. Persaingan \& Daya Saing, Kajian Strategis Globalisasi Ekonomi. Mida Pustaka: Jogjakarta.

Kartasasmita, Ginanjar. 1996. Pembangunan Untuk Rakyat. CIDES: Jakarta.

Indag Jabar. 2015. Pengembangan Industri Manufaktur Berbasis Tematik Kewilayahan. Disperindag Jabar: Bandung.

Partomo, Sartika and Sartika, Tiktik. 2008. Ekonomi Industri. Inti Prima: Jakarta.

Silalahi, Daud. 2001. Metodologi Penelitian Hukum-Preferensi Khusus Pada Pendekatan Multi/Interdisipliner. Lawencon Copy \& Binding Centre: Bandung.

Undang-Undang No. 20 Tahun 2008 tentang Usaha Mikro Kecil dan Menengah.

Undang-Undang No. 3 Tahun 2014 tentang Perindustrian.

Undang-Undang Nomor 28 Tahun 2014 tentang Hak Cipta.

Undang-Undang No. 14 Tahun 2001 tentang Hak Paten.

Undang-Undang No. 31 Tahun 2000 tentang Desain Industri.

Undang-Undang No. 32 Tahun 2000 tentang Desain Tata Letak Sirkuit Terpadu. 


\section{Biographies}

Nurhasan, born in Kuningan, West Java, August 4, 1966. He finished his Bachelor of Laws at the Faculty of Law in the Pasundan University of Bandung (1991). Continued taking courses Master of Law at the Graduate Programme Padjadjaran University of Bandung (2001). Until now works as a Lecturer at the Faculty of Law in the Pasundan University of Bandung. 